https://doi.org/10.48009/2_iis_2008_163-170

\title{
A CLUSTER ANALYSIS OF CAMPUS PORTAL IMPLEMENTATION
}

\author{
Suhong Li, Bryant University, sli@bryant.edu \\ Wallace A. Wood, Bryant University, wwood@bryant.edu
}

\begin{abstract}
This study investigates the status of portal implementation in the academic world. A two-stage cluster analysis was used to divide the sample colleges and universities into three groups (Internal Focus Implementers, External Focus Implementers and Starters) based on the portal features implemented by each school. The differences among the three groups were assessed based on the type of school and their status of portal adoption, implementation and evaluation. The results show that in terms of status of portal adoption and implementation, Internal Focus Implementers are the most advanced group, the External Focus group is in the middle and the Starters are the least advanced one. Most schools in the Internal Focus group are private schools, have the longest use of campus portals, favor Blackboard as the portal software, have widely shared responsibilities for the content of the portals, consider integration and implementation of a single logon as the biggest implementation challenges and are the most satisfied with their portal. In contrast, the Starters lag behind in terms of the adoption and implementation of the portal. For example, they have the shortest history of portal implementation, do not have dominant portal software, and have only one or two departments in charge of the content of the portal. In addition, they are the least satisfied with their portals.
\end{abstract}

Keywords: Campus portals, cluster analysis, portal adoption, portal implementation

\section{INTRODUCTION}

Portals, originally thought of as search engines whose purpose was to facilitate access to information spread through the Internet, eventually developed to be gateways to the Web that allow vast amounts of information available on Internet and intranet Web sites to be organized and customized through a single entry point [4]. Portals can thus be used to consolidate information from a vast array of sources, provide a centralized means of collaboration and offer a personalized workspace for both individuals and teams $[11 ; 14]$. Moreover, portals have the potential of providing organizations with a rich and complex shared information workspace for the generation, exchange, and use of knowledge [1].

\section{Classification of Portals}

Portals can be classified based on their environment, functions or scope. Based on the environment where they operate, portals can be public, corporate or campus. Public portals, also called Internet portals, provide a single interface to an immense network of Internet services [4]. MyYahoo is an example of a public portal. Corporate portals serve the needs of enterprises while campus portals serve the needs of universities/colleges. Both corporate and campus portals provide a single entry point to a variety of resources, to display customized and interactive information for various users, and to support users in fulfilling their functions. Corporate portals and campus portals can have different vendors and include different features because of different populations and environments.

Portals can also be categorized as information/content portals, collaborative portals, expertise portals and knowledge portals based on their functions [9]. The purpose of information/content portals is to organize large collections of content based on the subjects they contain and to connect people with this information. Collaborative portals use collaborative groupware tools and workflow systems to provide access to information produced by individuals or workgroups. Expertise portals link people together based on their skills and expertise, allowing real time communication and distance learning. Knowledge portals are the integration of the other types of portals and offer personalized content based on each user's job role [9].

Based on the scope/activities they cover, portals can be vertical or horizontal. Vertical portals provide access to a variety of information and services about a particular area of interest, such as sales, human resources, or course management. Horizontal portals offer access to almost all the information that an individual within a company/institution needs to carry out his or her function. According to this definition, horizontal portals embrace vertical portals. 


\section{Progress of Corporate and Campus Portals}

Portals hold the promise of delivering great value to organizations. Portals have the potential to reduce access time to information, improve employees' productivity, reduce information publishing costs, and enhance information distribution. Moreover, portals can facilitate collaborative work [3], allow enterprises to communicate with their trading partners more efficiently [10], improve data management, increase sales, improve customer service, expand marketing initiatives, and improve employee and customer satisfaction [12]. The benefits of portals have been confirmed by the realworld examples and survey results. For example, Hewlett-Packard had a first year savings of $\$ 50$ million by implementing a human resource portal and Whirlpool increased its sales from $\$ 7$ billion to $\$ 10$ billion without adding staff by using a business to business portal [12]. According to a Computerworld survey of 100 midsize and large organizations [2], corporate portals have been deployed to provide employees with multiple sources of data, streamline internal processes and increase employee productivity. Many studies of corporate portals have examined the usage, purpose, features, implementation issues, and the performance evaluation of them $[1 ; 3 ; 10 ; 11 ; 12 ; 13]$.

Impressed by the business sector, portals have become a topic of great interest for colleges and universities, who view the possibility of using the same technology to access, communicate and customize the university/college's internal information, to facilitate teaching and learning, to find new ways to connect with students, parents, and alumni, and to build community among their constituents in order to remain competitive in today's market for students [5]. A 2003 National Survey of Information Technology in US Higher Education (www.campuscomputing.net) revealed that 28\% of the institutions have web-based campus portals, up from $21 \%$ in 2002 . The Gartner group predicated that some $80 \%$ of US colleges with enrollments of more than 1000 would have campus portals by 2005 [8]. Campus Computing [6] reported that for public universities portal development increased from 28 percent to 74 percent between 2002 and 2006. The corresponding increases for private universities were 20 percent to 38 percent and 23 percent to 43 percent for community colleges.

There is little research concerning campus portals compared with the substantial research done regarding corporate portals. $\mathrm{Li}$ and Wood [7] investigated the adoption, implementation, and evaluation of campus portals based on a sample of 34 responses from members of the North East Regional Computing Program (NERCOMP). Their results showed that campus portals mainly serve the needs of internal users by displaying campus wide information to facilitate students in course related activities. The content of the portals in most schools was the responsibility of the IS/IT department. Integration and single logon were rated as the biggest challenges to implementing academic portals. The results indicate that most schools have not formally evaluated their portals. One limitation of the above study was the small sample size which limited the possibility of advanced data analysis.

The purpose of the current study is to extend the study of Li and Wood [7] by using a larger sample and by identifying, if possible, distinct groups of campus portal implementers based on portal features implemented by them, and by understanding the differences between each type of implementer. Specifically, this paper attempts to answer the following questions:

1) Can we identify and classify the implementers of campus portals into groups based on the features implemented by them?

2) If there are different groups, what are the differences among the groups in terms of their status of the adoption, implementation, and evaluation of campus portals?

\section{METHODOLOGY}

A survey methodology was adopted for this study. The survey items were first generated through an extensive literature search and then reviewed by several academicians involved in portal implementation. The focus was to check the relevance of each question and its clarity. Based on this feedback, redundant and ambiguous items were modified and eliminated. New items were added wherever necessary. The survey was pretested by a small sample of respondents for clarity and to determine the average length of completion time. The survey in its final form was placed on-line.

Members of EDUCAUSE (a non-profit organization comprised of over 2,200 members consisting of colleges, universities and educational organizations whose mission is to advance higher education by promoting the intelligent use of information technology) were asked to complete the survey and 115 usable responses were received and used in the following analysis. 


\section{Sample Demographics}

Table 1 also shows that the majority of respondents (85\%) are members of IT/IS departments. The surveyed colleges/universities are almost evenly divided between private and public institutions. Fifty percent of them offer doctoral degrees and $26 \%$ offer four year plus master degrees, while the schools offering four year and two year degrees account for $16 \%$ and $7 \%$ respectively.

Table 1. Demographic Information

\begin{tabular}{|l|c|c|}
\hline & Number & Percent \\
\hline Which of the following best describes you? \\
\hline Member of Faculty & 1 & $0.9 \%$ \\
\hline Member of administration & 14 & $12.2 \%$ \\
\hline Member of IS/IT department & 98 & $85.2 \%$ \\
\hline Other & 2 & $1.7 \%$ \\
\hline What is the type of your school? & 54 & $47.0 \%$ \\
\hline Public & 61 & $53.0 \%$ \\
\hline Private & 8 & $7.0 \%$ \\
\hline What is the highest degree offered at your school? & $16.7 \%$ \\
\hline two year & 19 & $26.3 \%$ \\
\hline Four year & 30 & $50.0 \%$ \\
\hline four year plus masters & 57 & \\
\hline doctoral degree &
\end{tabular}

\section{DATA ANALYSIS AND DISCUSSION}

For those portals already implemented, a two-stage cluster analysis was used to classify them into groups based on portal features implemented, followed by a comparison of the characteristics associated with each group.

\section{Cluster Analysis}

In the survey, the respondents were asked to indicate various features of portals implemented at their schools with 1 representing implemented and 0 representing not implemented. The features belong to four categories: student resources (11 items), campus resources (19 items), off-campus resources (10 items) and customization (4 items). See the Appendix for the list of 44 features.

A two stages cluster analysis was used to find if there were any underlying groups of the portal implementers based on the portal features implemented at the schools. The first stage adopts Ward's method to find the likely number of clusters. The portal features are used for categorization. Squared Euclidean distance is used to observe the similarity of each individual factor. The best group number can be determined by the progression of agglomeration coefficients. An increase in the agglomeration coefficient suggests an increase in the margins of error; therefore, the agglomeration process should be stopped to get the best collectivegroup number. Table 2 shows that when the number of groups changes from 3 to 2, the agglomeration coefficient increases the most; therefore the number of the groups should be 3 . K-means method is adopted for the second-stage analysis. The three groups derived for the first-stage's analysis should be used as starting points; further, three new groups will be determined according to the Euclidean distance. The samples of these three groups are: 19 in the first group, 11 for the second, and 23 for the third.

Table 3 shows the mean value of each category of portals features for each cluster. This value represents the percentage of features in each category implemented by the schools. It can be seen that the schools in Cluster 1 implemented $70 \%$ of the features related to campus resources and $60 \%$ of the features related to student resources; while the schools in Cluster 2 implemented $70 \%$ of the features related to off-campus resources and $60 \%$ of the features related to student resources. Schools in Cluster 3 have lower levels of portal feature implementation in most categories than do Cluster 1 and Cluster 2 groups In, sum, the schools in Cluster 1 and Cluster 2 have implemented the same level of portal features related to students resources while Cluster 1 focuses more on campus resources and Cluster 2 focuses more on offcampus resources. Therefore, Cluster 1 can be considered Internal Focus Implementers and Cluster 2 can be considered External Focus Implementers. In 
addition, because of its overall low implementation of portal features compared to the other two groups,
Cluster 3 can be considered the Starter group.

Table 2. Cluster Formation: Review of Agglomeration Coefficients

\begin{tabular}{|c|c|c|}
\hline Number of Cluster & $\begin{array}{c}\text { Within-Cluster sum of squares } \\
\text { Agglomeration coefficient }\end{array}$ & $\begin{array}{c}\text { Percentage change in coefficient } \\
\text { to next cluster level }\end{array}$ \\
\hline 10 & 16.73 & $0.4 \%$ \\
\hline 9 & 16.80 & $0.4 \%$ \\
\hline 8 & 17.10 & $1.8 \%$ \\
\hline 7 & 17.95 & $5.0 \%$ \\
\hline 6 & 18.14 & $1.1 \%$ \\
\hline 5 & 18.62 & $2.6 \%$ \\
\hline 4 & 18.96 & $1.9 \%$ \\
\hline 3 & 20.50 & $8.1 \%$ \\
\hline 2 & 21.49 & $4.8 \%$ \\
\hline
\end{tabular}

Table 3. The Mean Value of Each Category in Each Cluster

\begin{tabular}{|l|c|c|c|}
\hline & Cluster 1 (29) & Cluster 2 (11) & Cluster 3 (23) \\
\hline student resources & 0.6 & 0.6 & 0.3 \\
\hline campus resources & 0.7 & 0.4 & 0.3 \\
\hline off-campus resources & 0.5 & 0.7 & 0.4 \\
\hline customization & 0.4 & 0.6 & 0.5 \\
\hline
\end{tabular}

\section{Comparison of Campus Portal Implementers}

The following section will discuss the differences among the three groups based on the type of school and their status of portal adoption, implementation and evaluation.

\section{Type of School}

To test whether the type of the school differs among the three types of portal implementers, a chi-square test of homogeneity was performed. The results show that type of school does differ among the three groups, with a significance level less than .05 (see Table 4).

Table 5 shows that $43 \%$ of public schools belong to the Starter group and this number decreases to 30\% for private schools, indicating private schools have a higher level of portal content implementation than do public schools. In addition, 30\% and 26.7\% respectively of the surveyed public schools belong to the Internal Focus and the External focus groups, while for private schools, $60.6 \%$ of the schools belong to Internal Focus group and only $9 \%$ of them are in the External Focus group. Compared to public schools, portals at private schools tend to provide more campus-wide resources such as departmental and faculty web pages, campus event calendar, campus news and announcements, etc. They are less likely to provide off-campus resources such as social event information, local weather, regional/national/international news, and local movie listings.

Table 4. Chi-Square Test of Portal Implementers by School Type

\begin{tabular}{|c|c|c|c|c|c|c|c|}
\hline \multirow[t]{2}{*}{ School Type } & \multicolumn{2}{|c|}{$\begin{array}{l}\text { Internal Focus } \\
\text { Implementers }\end{array}$} & \multicolumn{2}{|c|}{$\begin{array}{l}\text { External Focus } \\
\text { Implementers }\end{array}$} & \multicolumn{2}{|c|}{ Starter } & \multirow{2}{*}{$\begin{array}{c}\text { Chi-square } \\
\text { Test }\end{array}$} \\
\hline & $\begin{array}{l}\text { Actual } \\
\text { Freq. }\end{array}$ & $\begin{array}{l}\text { Expect } \\
\text { ed } \\
\text { Freq. }\end{array}$ & $\begin{array}{l}\text { Actual } \\
\text { Freq. }\end{array}$ & $\begin{array}{c}\text { Expect } \\
\text { ed } \\
\text { Freq. }\end{array}$ & $\begin{array}{l}\text { Actual } \\
\text { Freq. }\end{array}$ & $\begin{array}{c}\text { Expect } \\
\text { ed } \\
\text { Freq. }\end{array}$ & \\
\hline Public & 9 & 13.8 & 8 & 5.2 & 13 & 11.0 & \multirow{3}{*}{$\begin{array}{c}\chi^{2}=6.74 \\
\mathrm{df}=2 \\
\mathrm{P}<0.05\end{array}$} \\
\hline Private & 20 & 15.2 & 3 & 5.8 & 10 & 12.0 & \\
\hline & 29 & 29 & 11 & 11 & 23 & 23 & \\
\hline
\end{tabular}


Table 5. Portal Implementers by School Type

\begin{tabular}{|l|c|c|c|c|c|c|c|}
\hline \multirow{2}{*}{} & \multicolumn{2}{|c|}{$\begin{array}{c}\text { Internal Focus } \\
\text { Implementers (29) }\end{array}$} & \multicolumn{2}{c|}{$\begin{array}{c}\text { External Focus } \\
\text { Implementers (11) }\end{array}$} & \multicolumn{2}{c|}{ Starter (23) } & \multirow{2}{*}{ Total } \\
\cline { 2 - 7 } & Number & $\%$ & Number & $\%$ & Number & $\%$ & \\
\hline Public & 9 & $30.0 \%$ & 8 & $26.7 \%$ & 13 & $43.3 \%$ & 30 \\
\hline Private & 20 & $60.6 \%$ & 3 & $9.1 \%$ & 10 & $30.3 \%$ & 33 \\
\hline
\end{tabular}

\section{Status of Portal Adoption, Implementation and Evaluation by Each Type of Portal Implementer}

Portal Adoption: Row 1 of Table 6 shows that $60 \%$ of the Internal Focus Implementers have portals in use for at least 3 years, while this figure decreased to $54 \%$ for the starter and $45 \%$ for the External Focus Implementers. In terms of software used for portals, Row 2 of Table 6 indicates that Blackboard is used by $64 \%$ of the Internal Focus Implementers and JASIG uPortal is implemented by $64 \%$ of the External Focus Implementers. It appears that there is no dominant software used for the Starters. Row 3 of Table 6 shows that about $70 \%$ of the schools in the External Focus Implementers have used more than three types of portal software packages; while for Internal Focus Implementers and the Starters, this number decreased to $51 \%$ and $47 \%$ respectively. Row 3 of Table 6 also shows that almost half (43\%) of the Starters used only one portal software package. In sum, it can be seen that the Starters have a shorter history of portal implementation, use fewer portal software packages and have no dominant software package for their portal implementation.

Status of Portal Implementation by Type of Portal Implementer: Row 1 of Table 7 shows that the major constituents served by the portals are students, faculty and staff. It also can be seen that more schools in the Internal Focus Implementers have served parents and alumni than the other two groups. It is interesting to see that $35 \%$ of the schools in the starter group also serve applicants; this number is much higher than the other two groups.

Table 6. Status of Portal Adoption by Each Type of Portal Implementer

\begin{tabular}{|c|c|c|c|c|c|c|c|}
\hline \multirow{2}{*}{\multicolumn{2}{|c|}{ Status of Portal Adoption }} & \multicolumn{2}{|c|}{$\begin{array}{c}\text { Internal Focus } \\
\text { Implementers(29) }\end{array}$} & \multicolumn{2}{|c|}{$\begin{array}{c}\text { External Focus } \\
\text { Implementers (11) }\end{array}$} & \multicolumn{2}{|c|}{ Starter (23) } \\
\hline & & Number & $\%$ & Number & $\%$ & Number & $\%$ \\
\hline \multirow{3}{*}{$\begin{array}{l}\text { 1. Length of } \\
\text { Portal Use }\end{array}$} & 1-2 year & 11 & $41 \%$ & 6 & $55 \%$ & 10 & $45 \%$ \\
\hline & 3-4 year & 15 & $56 \%$ & 5 & $45 \%$ & 9 & $41 \%$ \\
\hline & $>4$ year & 1 & $4 \%$ & 0 & $0 \%$ & 3 & $14 \%$ \\
\hline \multirow{5}{*}{$\begin{array}{l}\text { 2.Software } \\
\text { Packages } \\
\text { Used for } \\
\text { Portals }\end{array}$} & Blackboard & 14 & $63.60 \%$ & 5 & $45.50 \%$ & 6 & $20.00 \%$ \\
\hline & Home-grown & 9 & $40.90 \%$ & 2 & $18.20 \%$ & 4 & $13.30 \%$ \\
\hline & Campus Pipeline & 7 & $31.80 \%$ & 1 & $9.10 \%$ & 1 & $3.30 \%$ \\
\hline & JA-SIG uPortal & 7 & $31.80 \%$ & 7 & $63.60 \%$ & 8 & $26.70 \%$ \\
\hline & Oracle & 3 & $13.60 \%$ & 1 & $9.10 \%$ & 4 & $13.30 \%$ \\
\hline \multirow{4}{*}{$\begin{array}{l}\text { 3. Number of } \\
\text { Software } \\
\text { Packages } \\
\text { Used }\end{array}$} & 1 & 9 & $31 \%$ & 3 & $30 \%$ & 10 & $43 \%$ \\
\hline & 2 & 5 & $17 \%$ & 0 & $0 \%$ & 2 & $9 \%$ \\
\hline & 3 & 12 & $41 \%$ & 6 & $60 \%$ & 10 & $43 \%$ \\
\hline & $>=4$ & 3 & $10 \%$ & 1 & $10 \%$ & 1 & $4 \%$ \\
\hline
\end{tabular}

Row 2 of Table 7 shows that the majority of the schools in the three groups indicate their IT/IS departments are responsible for the content of the portals. Besides IT/IS department, students affairs is mentioned by almost half (45\%) of the schools in the Internal and External Implementers groups. 
Row 3 of Table 7 shows that for the Starter group, $78 \%$ of the schools have only one or two departments responsible for the content of the portal. For the other two groups, half of the schools have more than three departments in charge of the content of the portal. It can be seen that $45 \%$ of Internal Focus Implementers have at least four departments responsible for the content of the portals, reflecting a widely shared responsibility in terms of the content creations in this group.

In terms of implementation challenges, Row 4 of Table 7 indicates that integration and implementation of a single logon are the top two concerns for Internal Focus Implementers and the Starters. On the other hand, lack of cooperation, collaboration and buy-in are the most challenging issues for the External Focus group.

Status of Evaluation and Satisfaction of Portals by Type of Implementers: Row 1 of Table 8 shows that fewer schools in the Internal Focus Implementers group have evaluated their portals compared to External Focus Implementers and the Starters. Row 2 of Table 8 reveals that Internal Focus Implementers are more satisfied with their portals since 57\% indicate that they are either considerably satisfied or very much satisfied, and this number decreases to 45\% and $41 \%$ for External Focus Implementers and the Starters respectively.

Table 7. Status of Portal Implementation by Portal Implementers

\begin{tabular}{|c|c|c|c|c|c|c|c|}
\hline \multirow{2}{*}{\multicolumn{2}{|c|}{ Status of Portal Implementation }} & \multicolumn{2}{|c|}{$\begin{array}{l}\text { Internal Focus } \\
\text { Implementers }\end{array}$} & \multicolumn{2}{|c|}{$\begin{array}{l}\text { External Focus } \\
\text { Implementers }\end{array}$} & \multicolumn{2}{|c|}{ Starter } \\
\hline & & Number & $\%$ & Number & $\%$ & Number & $\%$ \\
\hline \multirow{6}{*}{$\begin{array}{l}\text { 1.Key } \\
\text { Constituents } \\
\text { Served by } \\
\text { Portals }\end{array}$} & Students & 28 & $97 \%$ & 10 & $91 \%$ & 21 & $91 \%$ \\
\hline & Faculty & 29 & $100 \%$ & 10 & $91 \%$ & 20 & $87 \%$ \\
\hline & Staff & 26 & $90 \%$ & 9 & $82 \%$ & 18 & $78 \%$ \\
\hline & Applicants & 5 & $17 \%$ & 1 & $9 \%$ & 8 & $35 \%$ \\
\hline & Parents & 4 & $14 \%$ & 0 & $0 \%$ & 2 & $9 \%$ \\
\hline & Alumni & 8 & $28 \%$ & 0 & $0 \%$ & 2 & $9 \%$ \\
\hline \multirow{6}{*}{$\begin{array}{l}\text { 2. Department } \\
\text { responsible for } \\
\text { the content of } \\
\text { the portals }\end{array}$} & Academic office & 13 & $45 \%$ & 4 & $36 \%$ & 3 & $13 \%$ \\
\hline & IT/IS department & 23 & $79 \%$ & 10 & $91 \%$ & 19 & $83 \%$ \\
\hline & Student Affairs & 13 & $45 \%$ & 5 & $45 \%$ & 8 & $35 \%$ \\
\hline & Academic Affairs & 11 & $38 \%$ & 4 & $36 \%$ & 5 & $22 \%$ \\
\hline & Business Affairs & 9 & $31 \%$ & 1 & $9 \%$ & 4 & $17 \%$ \\
\hline & College Relations & 13 & $45 \%$ & 2 & $18 \%$ & 3 & $13 \%$ \\
\hline \multirow{4}{*}{$\begin{array}{l}\text { 3. Number of } \\
\text { department } \\
\text { responsible for } \\
\text { the content of } \\
\text { the portal }\end{array}$} & 1 & 13 & $45 \%$ & 4 & $36 \%$ & 11 & $48 \%$ \\
\hline & 2 & 2 & $7 \%$ & 1 & $9 \%$ & 7 & $30 \%$ \\
\hline & 3 & 1 & $3 \%$ & 3 & $27 \%$ & 2 & $9 \%$ \\
\hline & $>=4$ & 13 & $45 \%$ & 3 & $27 \%$ & 3 & $13 \%$ \\
\hline \multirow{4}{*}{$\begin{array}{l}4 . \\
\text { Implementation } \\
\text { Challenges }\end{array}$} & Integration & 23 & $79 \%$ & 8 & $73 \%$ & 17 & $74 \%$ \\
\hline & $\begin{array}{l}\text { Implementation of a } \\
\text { single logon }\end{array}$ & 19 & $66 \%$ & 7 & $64 \%$ & 16 & $70 \%$ \\
\hline & $\begin{array}{l}\text { Lack of cooperation, } \\
\text { collaboration, and } \\
\text { buy-in }\end{array}$ & 10 & $34 \%$ & 9 & $82 \%$ & 10 & $43 \%$ \\
\hline & Security issues & 11 & $38 \%$ & 3 & $27 \%$ & 7 & $30 \%$ \\
\hline
\end{tabular}




\section{CONCLUSIONS}

This study identifies three groups of portal implementers: Internal Focus Implementers, External Focus Implementers and the Starters. Considerable differences were found among these three groups in terms of type of school, and the adoption, implementation and evaluation of the portals. Most of the Internal Focus Implementers are private schools, have the longest term of use of campus portals, favor Blackboard as the portal software, have widely shared responsibilities for the content of the portals and consider integration and implementation of a single logon as the biggest implementation challenges. Although most of them have not evaluated their portals, they are the most satisfied with their portals. For the External Focus Implementers, the majority of them are public colleges/universities, tend to adopt JA-SIG uPortal software, have used more types of portal software than Internal Focus Implementers, have not served parents and alumni, have moderately shared responsibilities for the content of the portals and consider lack of cooperation and buy-in as the biggest implementation challenges, and are less satisfied with their portals. Compared to the Internal and External Focus groups, the Starters lag behind in terms of the adoption and implementation of their portals. For example, they have a shorter history of portal implementation, do not have a dominant portal software package, have only one or two departments in charge of the content of the portal and are the least satisfied with their portals. The above analysis shows that in terms of status of portal adoption and implementation, Internal Focus Implementers are the most advanced group, the External group is in the middle and the Starters are the least advanced.

Table 8. Status of Portal Evaluation and Satisfaction by Each Type of Implementers

\begin{tabular}{|c|c|c|c|c|c|c|c|}
\hline \multirow{2}{*}{\multicolumn{2}{|c|}{ Portal Evaluation and Satisfaction }} & \multicolumn{2}{|c|}{$\begin{array}{c}\text { Internal Focus } \\
\text { Implementer (28) }\end{array}$} & \multicolumn{2}{|c|}{$\begin{array}{c}\text { External Focus } \\
\text { Implementers (11) }\end{array}$} & \multicolumn{2}{|c|}{ Starter (23) } \\
\hline & & Number & $\%$ & Number & $\%$ & Number & $\%$ \\
\hline \multirow{2}{*}{$\begin{array}{l}\text { 1.Have you } \\
\text { Evaluated the } \\
\text { Portal }\end{array}$} & Yes & 5 & $20.0 \%$ & 3 & $27.3 \%$ & 6 & $26.1 \%$ \\
\hline & No & 20 & $80.0 \%$ & 8 & $72.7 \%$ & 17 & $73.9 \%$ \\
\hline \multirow{5}{*}{$\begin{array}{l}\text { 2.Satisfaction of } \\
\text { Portals }\end{array}$} & Not satisfied & 0 & $0 \%$ & 0 & $0 \%$ & 1 & $5 \%$ \\
\hline & Little satisfied & 1 & $4 \%$ & 0 & $0 \%$ & 3 & $14 \%$ \\
\hline & $\begin{array}{l}\text { Moderately } \\
\text { satisfied }\end{array}$ & 11 & $39 \%$ & 6 & $55 \%$ & 9 & $41 \%$ \\
\hline & $\begin{array}{l}\text { considerably } \\
\text { satisfied }\end{array}$ & 13 & $46 \%$ & 3 & $27 \%$ & 6 & $27 \%$ \\
\hline & $\begin{array}{l}\text { Very much } \\
\text { satisfied }\end{array}$ & 3 & $11 \%$ & 2 & $18 \%$ & 3 & $14 \%$ \\
\hline
\end{tabular}

\section{References}

1. Benbya, H., Passiante, G. Belbaly, N. A., "Corporate portal: a Tool for Knowledge Management Synchronization”, International Journal of Information Management, 24(3), 2002, pp.201-220.

2. Connolly, J. M., "Portals: the Place to Be", ComputerWorld, August 9, 1999. Retrieved August 2004 from http://www.computerworld.com/printthis/1999/0, 4814,36605,00.html

3. Deltor, B., "The Corporate Portal as Information Infrastructure: Towards a Framework for Portal Design”, International Journal of Information Management, 20(2), 2000, pp.91-101.
4. Dias, C., "Corporate Portals: a Literature Review of a New Concept in Information Management", International Journal of Information Management, 21(4), 2001, pp. 269-287.

5. Godfre, W., and L Haffner,. (2003), "Transforming Portals from Gateways to Enablers of Institutional Goals”, Syllabus Magazine, Retrieved March 24, 2008 from http://campustechnology.com/articles/39514_3/

6. Heid, S. D. (2007), “All Roads Lead to Portal,” Campus Technology. Retrieved March 24, 2008 from http://campustechnology.com/articles/47751_3/

7. Li, S. and W. Wood,.(2005), "Portals in the Academic World: Are They Meeting Expectations?”, Journal of Computer Information Systems, 45(4), pp.50-55 
8. Moskowitz, R., “Campus portals come to higher education”, Matrix, June, 2001, pp.54-56.

9. Murray. G., "The Portal is the Desktop," Intraspect, Inc., 1999, Los Altos, CA.

10. Norris, G., \& Duray, D. J., “The Outside-in Portal”, Intelligence Enterprise, August 12, 2002, pp.32-35.

11. Roberts-Witt, S. L., "Portal Pitfalls”, Knowledge Management, October, 2000, pp.42-46.
12. Rose, J. G., “The Joys of Enterprise Portals”, The Information Management Journal, 37(5), 2003, pp.64-70.

13. Roth, C., “Top 10 Portal Pitfalls”, META Group, May 2, 2002. Retrieved March 24, 2008 from http://www.ingroup.co.uk/pdf/top_ten_pitfalls.pdf

14. Watson, J. \& Fenner, J., “Understanding Portals”, The Information Management Journal, 34(3), 2000, pp.18-22.

\section{Appendix: Campus Portal Features}

\section{Student Resources}

1. Link to email and email Alerts

2. Personal Calendar

3. Grades: Record of unofficial transcript, midterm and final grades

4. GPA calculator

5. Online registration for classes

6. Library Information: Status of books ordered via Consort/Ohio Link, new books available, late fees

7. Articles on electronic reserve for classes

8. Advisor look-up

9. Access to Blackboard, WebCT or other course management packages

10. Workspace/file storage and sharing

11. Financial aid status, access to online financial aid forms

\section{Campus Resources}

1. Online course catalog

2. Departmental and faculty web pages: Policies, procedures, questions, programs

3. Campus events calendar

4. Recreation and intramural activities and schedules, facilities

5. Sports scores, upcoming varsity athletic events

6. University Deadlines

7. Campus news and announcements, e.g., road closings, service interruptions, weather alerts

8. Campus tour
9. Campus directory

10. Student Activity Council events

11. Student Publications

12. On-Campus job postings

13. Bulletin board for campus wide discussion

14. Online surveys and polls

15. Bookstore online purchases

16. Internship/career databases

17. Student Handbook

18. Online training, e.g., Web publishing tutorials

19. Employee salary statements

\section{Off-campus Resources}

1. Internet search engine links

2. Personal links and bookmarks

3. Social event information

4. Local weather

5. Regional news

6. National news

7. International news

8. Foreign national news

9. New release books/music/film

10. Local movie listings

\section{Customization}

1. Manage personal portfolio

2. A single login

3. Change the look and feel of the portal screen

4. Control what information is displayed in the portal screen and where it appears 